\title{
Karakterisasi Protein VirB4 Brucella abortus Isolat Lokal dengan Teknik Sodium Dodecyl Sulfate Polyacrylamide Gel Electrophoresis
}

\author{
(CHARACTERIZATION OF VirB4 PROTEIN FROM LOCAL ISOLATE \\ OF BRUCELLA ABORTUS USING SODIUM DODECYL SULFATE \\ POLYACRYLAMIDE GEL ELECTROPHORESIS TECHNIQUE) \\ Ratih Novita Praja ${ }^{1}$, Didik Handijatno ${ }^{1}$, \\ Setiawan Koesdarto ${ }^{2}$, Aditya Yudhana ${ }^{2}$ \\ ${ }^{1}$ Laboratorium Bakteriologi dan Mikologi, Departemen Mikrobiologi, \\ ${ }^{2}$ Laboratorium Helmintologi, Departemen Parasitologi Veteriner, \\ Fakultas Kedokteran Hewan, Universitas Airlangga, \\ Kampus-C Unair, Jln. Mulyorejo, Surabaya, \\ Jawa Timur, Indonesia, 60115 \\ Telp. (031) 5993016, Fax (031) 5990315 \\ Email: ratihvet.unair@gmail.com
}

\begin{abstract}
ABSTRAK
Brucellosis merupakan salah satu penyakit zoonosis yang disebabkan oleh bakteri patogen genus Brucella. Penyakit ini menyerang hewan ternak mamalia seperti sapi, kambing, babi, dan dapat menular ke manusia. Bakteri Brucella abortus memiliki faktor virulensi potensial yaitu protein VirB. Type IV Secretion System (T4SS) merupakan gabungan dari 12 protein yaitu VirB1-VirB11 dan VirD4. Brucella dapat bertahan hidup lama di dalam lingkungan meskipun memiliki keterbatasan nutrisi dan oksigen. Penelitian ini dilakukan untuk karakterisasi protein VirB4 B. abortus isolat lokal dengan metode Sodium Dodecly Sulfate-Polyacrylamide Gel Electrophoresis (SDS PAGE). Hasil karakterisasi protein B. abortus isolat lokal dengan teknik SDS-PAGE terdapat 10 pita protein dengan bobot molekul 158,93; 110,89; 99,931; 70,60; 64,61; 59,25; 45,32; 42,35; 23,63; dan 16,70 kDa. Simpulan penelitian ini adalah terdapat protein VirB4 B. abortus isolat lokal yang mempunyai bobot molekul $59,25 \mathrm{kDa}$.
\end{abstract}

Kata-kata kunci: Brucella abortus; VirB4; SDS-PAGE

\begin{abstract}
Brucellosis is a zoonotic disease cause by pathogenic bacteria of the genus Brucella. The disease infects livestock mammals such as cows, goats, pigs, and including humans. Brucella abortus has several potential virulence factors, i.e. Proteins VirB. Type IV secretion system (T4SS) which is a combination of 12 proteins from VirB1-VirB11 and VirD4. Brucella can survive for long periods in the environment despite the limitations of nutrients and oxygen. This study aims to characterize the protein VirB4 of local isolate of B. abortus using SDS PAGE (Sodium Dodecly sulfate-polyacrylamide gel electrophoresis). The results showed that the protein contained 10 protein bands with a molecular weight of $158.93 ; 110.89$; 99.931; 70.60; 64.61; 59.25; 45.32; 42.35; 23.63; and $16.70 \mathrm{kDa}$, respectively. Protein VirB4 of the local isolate of B. abortus have a molecular weight of $59.25 \mathrm{kDa}$.
\end{abstract}

Keywords: Brucella abortus; VirB4; SDS-PAGE 


\section{PENDAHULUAN}

Brucellosis merupakan salah satu penyakit zoonosis yang bisa berdampak negatif pada kesehatan masyarakat dan perekonomian di dunia. Brucellosis disebabkan oleh bakteri patogen genus Brucella. Penyakit ini menyerang hewan ternak mamalia seperti sapi, kambing, babi, dan dapat menular ke manusia (Agasthya, 2007). Infeksi B. abortus yang menyerang sapi dapat menyebabkan abortus pada bulan ke-6 sampai ke-9 periode kebuntingan (Toelihere, 1985). Kejadian abortus berkisar antara 5-9\% di dalam suatu kelompok ternak tergantung pada berat ringannya kasus infeksi, daya tahan hewan, dan tingkat virulensi bakteri (Sudibyo, 1995). Meskipun telah lama dilakukan pengendalian dengan program vaksinasi menggunakan vaksin S19 dan vaksin RB51, kejadian brucellosis masih tergolong tinggi (Noor, 2006).

Brucellosis pada manusia dikenal dengan Malta fever, Mediterranean fever, dan Gilbaltar fever sesuai dengan nama daerah tempat pertama kali penyakit ini ditemukan. Brucellosis juga dikenal sebagai nama undulant fever karena gejala demam dengan suhu yang bervariasi dan berulang pada orang yang terinfeksi (Megid et al., 2010). Infeksi Brucella $s p$ pada manusia tidak menyebabkan keguguran tetapi hanya menimbulkan gejala klinis antara lain: demam intermitten, sakit kepala, myalgia, malaise, nyeri, dan gangguan pencernaan. Infeksi penyakit ini ditularkan secara langsung maupun tidak langsung melalui kontak dengan hewan atau produk hewan yang terinfeksi (Pasquevich, 2010).

Respons imun untuk menghadapi brucellosis melibatkan antara sistem imun humoral dan seluler. Brucella abortus memiliki faktor virulensi potensial yaitu protein VirB. Pada golongan koloni halus (smooth) Brucella dapat masuk ke dalam sel inang melalui interaksi sel permukaan yang tersusun dari ikatan lipid. Brucella melakukan penetrasi melalui sel epitel dan menyebar dalam sel inang menuju limfonodus regional dan kemudian ke jaringan yang berbeda. Spesies Brucella dapat bertahan hidup dan bereplikasi dalam sel fagosit (Splitter, 2003). Bakteri patogen yang dapat bertahan hidup secara intraseluler, harus mengatasi mekanisme bakterisida yang dikeluarkan oleh sel inang (Lin, 1995). Bakteri patogen intraseluler telah mengembangkan berbagai cara untuk menghindari pertahanan inang atau degradasi bakteri, seperti mengendalikan pematangan sel fagosit dan mentransformasikannya ke dalam lingkungan yang kaya nutrisi sehingga bakteri bisa bereplikasi (Celli et al., 2003).

Pengamatan dalam interaksi seluler beserta masuknya bakteri Brucella ke dalam makrofag telah menunjukkan bahwa bakteri tersebut berhubungan dengan sistem keasaman phagosome. Kondisi asam tersebut penting untuk stimulasi ekspresi virulensi protein vir B yang berhubungan dengan munculnya sistem sekresi tipe IV B. abortus (Rouot et al., 2003). Type IV Secretion System (T4SS) merupakan gabungan dari 12 protein yaitu VirB1-VirB11 dan VirD4. VirB4, VirB11, dan VirD4 saling berinteraksi satu sama lain sebagai ATPase. Secara keseluruhan menunjukkan bahwa VirB merupakan faktor yang menyebabkan Brucella dapat bertahan hidup dengan memengaruhi ekspresi gen lain dan memodifikasi jalur sinyal sel inang (Nijskens et al., 2008). Tujuan dari penelitian ini adalah untuk mengetahui karakter protein VirB4 dan menjelaskan bobot molekul protein VirB4 B.abortus isolat lokal.

\section{METODE PENELITIAN}

Penelitian ini dilakukan di Laboratorium Bakteriologi, Laboratorium Biologi Molekuler Veteriner, Fakultas Kedokteran Hewan, Universitas Airlangga Surabaya. Sampel penelitian yang digunakan adalah bakteri $B$. abortus isolat lokal Indonesia dari Laboratorium Bateriologi dan Mikologi, FKH Unair.

Penelitian ini dilakukan untuk mengkarakterisasi protein VirB4 B. abortus isolat lokal dengan metode Sodium Dodecyl Sulfate Polyacrylamide Gel Electrophoresis (SDS PAGE). Bakteri B. abortus ditanam pada media Brucella Agar Medium (BAM) kemudian diidentifikasi dengan pewarnaan Gram serta uji biokimia menggunakan uji urease, uji sitrat, uji Sulfide Indole Motility (SIM), dan uji Triple Sugar Iron Agar (TSIA). Bakteri B. abortus isolat lokal dikultur dalam media Tryptic Soy Broth sebanyak satu liter dan diletakkan pada shaker incubator dengan suhu $37^{\circ} \mathrm{C}$ dan kecepatan $75 \mathrm{rpm}$ selama $36 \mathrm{jam}$, setelah $36 \mathrm{jam}$ sampel disentrifugasi dengan kecepatan 5000 rpm selama 10 menit untuk mendapatkan pelet. Pelet yang didapatkan ditambahkan PBS steril $5 \mathrm{~mL}$ lalu dilakukan sonikasi dengan kecepatan amplitudo 30\% selama satu menit selang 15 detik 
diulang sebanyak 30 kali pada suhu $4^{\circ} \mathrm{C}$ yang dipertahankan dengan menambahkan es di sekitar tabung. Sampel yang telah disonikasi kemudian disentrifugasi $12.000 \mathrm{rpm}$ selama 10 menit lalu supernatan yang diperoleh dipisahkan dari pelet untuk diseparasi dengan teknik SDS PAGE (Ali et al., 2006).

Protein pada $B$. abortus yang telah diekstraksi diambil sebanyak 50 ì ditambahkan Laemmli buffer 50 iL (1:1) dan dipanaskan pada suhu $100^{\circ} \mathrm{C}$ selama tujuh menit dan dipersiapkan larutan separating gel 12\% yang terdiri dari Acrylamide 30\%, Tris $\mathrm{HCl} \mathrm{pH}$ 8,8 , SDS $10 \%$, ammonium persulfate solution (APS) 10\%, aquadest, dan tetra methyl ethylene diamine (TEMED) dalam beaker glass, dan dimasukan pada plat kaca yang telah disiapkan dan ditambah aquadest sampai mengeras. Aquadest dibuang dan dikeringkan dengan kertas whatmann. Proses selanjutnya adalah ditambahkan stacking gel 4\% (Acrylamide 30\%, Tris $\mathrm{HCl} \mathrm{pH}$ 6,8, SDS 10\%, APS 10\%, aquadest, dan TEMED) pada atas gel, kemudian comb dimasukan kedalam gel, dibiarkan sampai mengeras dan angkat comb perlahan-lahan, masukkan dalam kotak SDS-PAGE appratus kemudian tambahkan elektroforesis buffer (Glycine, SDS, Tris Base, dan Aquadest), marker protein serta sampel dimasukan dalam masingmasing sumuran kolom sebanyak $5 \mu \mathrm{L}$ untuk marker dan $10 \mu \mathrm{L}$ untuk sampel lalu running 100 volt selama 100 menit (Roy, 2012).

Gel diangkat dari plat kaca setelah running selesai, secara hati-hati, dicuci dengan aquadest untuk menghilangkan larutan elektoforesis kemudian diangkat dan dimasukan dalam larutan pewarna commasie blue, digoyanggoyangkan dengan kecepatan 50 rpm selama 30 menit, selanjutnya dibilas dengan larutan destaining (methanol absolut, acetid acid dan aquadest), dibilas hingga gel terlihat bening dan pita protein terlihat dengan jelas. Hasil gel dapat didokumentasikan dan disimpan dalam larutan aquadest serta dianalisis untuk menentukan bobot molekul dengan metode regulasi yaitu jarak (cm) pita-pita protein dari batas gel pemisah dibagi jarak $(\mathrm{cm})$ tracking dye dari batas atas gel pemisah (Rand, 2011).

\section{HASIL DAN PEMBAHASAN}

Hasil identifikasi B. abortus isolat lokal yang ditumbuhkan pada media Brucella Agar Medium (BAM) diperoleh koloni bakteri yaitu berbentuk bulat, halus, berwarna kuning mengkilat seperti madu. Hasil identifikasi $B$. aboruts dengan pewarnaan Gram yaitu bersifat Gram negatif, berbentuk coccobacillus, bergerombol atau berpasangan, dan tidak berkapsul.

Pemeriksaan dengan melakukan uji biokimia menggunakan uji urease, uji sitrat, uji SIM, dan uji TSIA. Uji urease menunjukkan hasil positif ditandai dengan perubahan warna media dari kuning menjadi kemerahan. Uji sitrat menunjukkan hasil negatif ditandai dengan tidak ada perubahan warna pada media. Pada uji indol menunjukkan hasil yang negatif ditandai dengan tidak terbentuknya cincin berwarna merah muda pada ujung tabung. Pada media TSIA menunjukkan hasil butt dan slant bersifat alkali ditandai dengan warna merah pada bagian atas dan bawah media serta tidak membentuk gas. Uji katalase menunjukkan hasil positif, hasil positif dari uji katalase ditandai dengan gelembung udara sebagai reaksi pemecahan $\mathrm{H}_{2} \mathrm{O}_{2}$ oleh enzim katalase menjadi $\mathrm{H}_{2} \mathrm{O}$ dan $\mathrm{O}_{2}$ Pemeriksaan bakteriologis tersebut bermanfaat untuk menegaskan bahwa bakteri yang diisolasi adalah $B$. abortus melalui sifat biokimiawi (Sangari et al., 2000).

Sodium Dodecyl Sulfate-Polyacrylamide Gel Electrophoresis (SDS-PAGE) merupakan teknik elektroforesis yang digunakan untuk menentukan bobot molekul protein yang belum diketahui. Prinsip dasar SDS-PAGE adalah denaturasi protein oleh Sodium Dodecyl Sulfate (SDS) dilanjutkan dengan separasi molekul berdasarkan metode elektroforesis dengan menggunakan gel polyacrilamide (Novagen et al., 2007). Bobot molekul protein dapat diketahui dengan membandingkan protein dengan protein marker yang bobot molekulnya telah diketahui (Wilson dan Walker, 2010).

Pada hasil running dengan SDS-PAGE terdapat pita protein yang dominan dengan warna yang tebal dan ada yang diekspresikan dengan bentuk pita yang tipis. Hal ini mungkin disebabkan oleh tingkat kemurnian yang baik dan konsentrasi protein yang cukup (Wilson dan Walker, 2010). Hasil penghitungan BM protein B.abortus diperoleh 10 pita protein, yaitu 158,93; 110,$89 ; 99,93 ; 70,60 ; 64,61 ; 59,25 ; 45,32 ; 42,35$; 23,63; dan 16,70 kDa termasuk protein VirB4 di dalamnya yaitu sebesar 59,25 kDa. Pengitungan BM protein menggunakan persamaan regresi antara nilai retardation factor (rf) dengan log BM pada marker. Nilai rf diperoleh dari pembagian jarak (antara gel 


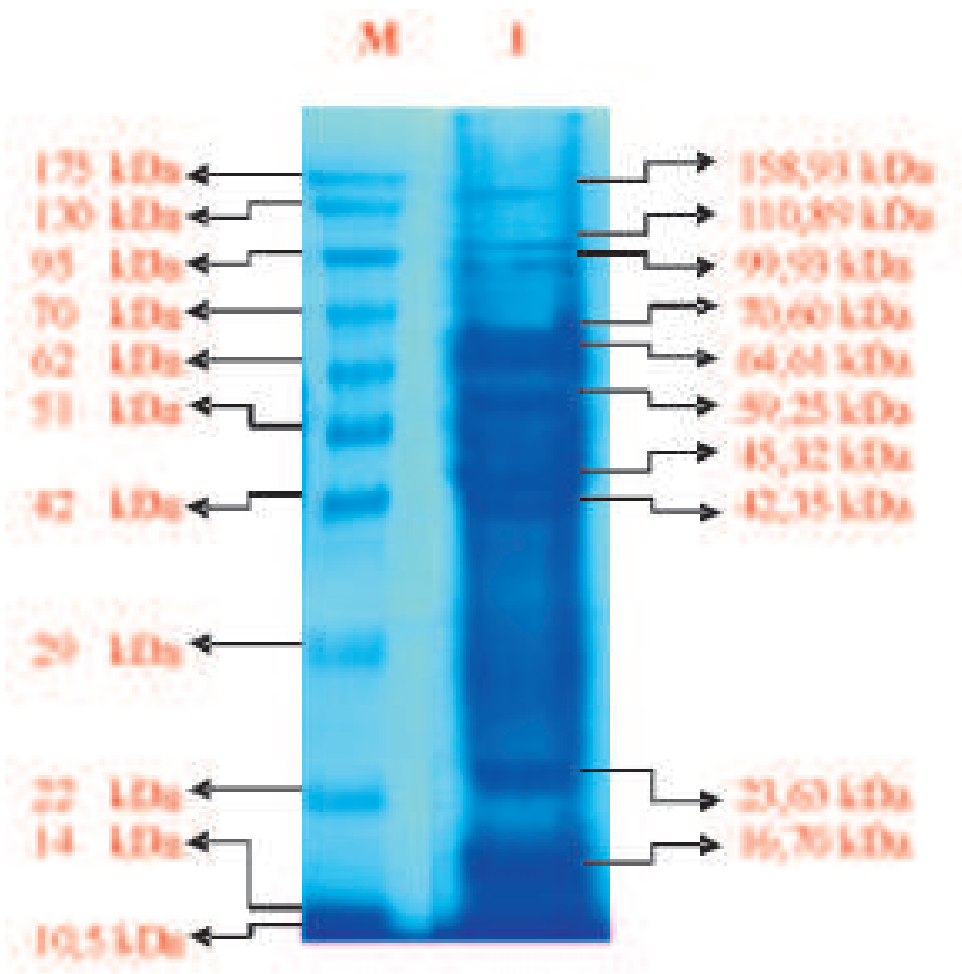

Gambar 1. Hasil identifikasi protein Brucella abortus isolat lokal dengan teknik SDS PAGE, M adalah Marker dan Kolom 1 adalah B.abortus isolat lokal.

preparasi dengan pita yang berbentuk pada marker) dengan panjang gel. Hasil analisis regresi menggunakan Statistical Product and Service Solution (SPSS) 20 for Windows antara nilai rf dan log BM (Da) protein pada marker didapatkan bentuk kubik sehingga didapatkan persamaan garis $\mathrm{y}=2,561-3,847 \mathrm{x}+5,445 \mathrm{x}^{2}$ $3,099 \mathrm{x}^{3}$ dan digunakan untuk perhitungan BM protein pada sampel, dengan y $=\log \mathrm{BM}(\mathrm{Da})$ dan x nilai rf pada sampel (Novagen et al., 2007). Keberhasilan running dengan teknik SDSPAGE dipengaruhi oleh beberapa hal antara lain kebersihan isolat, tingkat kemurnian isolate, dan kadar protein dalam homogenat. Selain itu, dipengaruhi oleh mobilisasi protein pada saat melakukan analisis SDS-PAGE. Kebersihan dan kemurnian homogenat memengaruhi tingkat resolusi yang tinggi pada pita protein. Pita terlihat tajam dan terang sehingga memudahkan analisis protein dan dokumentasi. Isolat yang murni dan kadar protein homogenat yang baik akan menghasilkan pita protein yang baik dan jelas sehingga dapat memudahkan analisis bobot molekul pada pita yang terbentuk (Novagen et al., 2007).

Brucella yang masuk dalam sel inang, langsung menuju lalu lintas vacuolar dalam sel fagosit dengan cara menghindari endositosis dan menghambat penyatuan phagosome-lisosom. Transit Brucella ke dalam sel melalui Brucella Containing Vacuole (BCV). Interaksi selanjutnya dari BCV ini dengan membran Endoplasmic Reticulum (ER) memungkinkan bakteri melakukan proses maturasi dan replikasi intraseluler sehingga bakteri dapat berkembang biak (Pitt et al., 1992). Brucella menampilkan karakteristik virulensi yang unik, salah satu faktor penentu virulensi yaitu protein $\operatorname{Vir} \mathrm{B}$ (Pizzaro et al., 1998).

Dalam semua organisme hidup, sistem sekresi memediasi bagian dari makromolekul yang melintasi membran sel. Sekresi tersebut sangat penting untuk virulensi dan kelangsungan hidup pada bakteri. Sistem sekresi tipe IV (T4SS) merupakan gabungan dari 12 protein yaitu VirB1-VirB11 dan VirD4. Senyawa T4SS umumnya memiliki tiga ATPase khusus yang membentuk pusat energi sekresi. Senyawa ATPase ini merupakan protein penyusun system sekresi yang diberi nama VirD4, VirB11, dan VirB4. Ketiga protein tersebut sangat penting untuk sistem sekresi pada bakteri Gram negatif. Oleh karena itu, protein tersebut cenderung membentuk kompleks ATPase besar yang memberi energi transportasi substrat dari sitoplasma melalui mekanisme translokasi. 
Vir B11 berinteraksi langsung dengan VirB4 dan VirD4 melibatkan domain di dekat daerah pusat dari kedua protein yang berada di dalam atau di dekat membran dalam (Taminiau et al., 2002).

\section{SIMPULAN}

Hasil karakterisasi protein B. abortus isolat lokal dengan teknik SDS-PAGE terdapat 10 pita protein dengan bobot molekul 158,93; 110,89; 99,931; 70,60; 64,61; 59,25; 45,32; 42,35; 23,63; dan $16,70 \mathrm{kDa}$. Protein VirB4 B. abortus isolat lokal mempunyai bobot molekul 59,25 kDa.

\section{SARAN}

Berdasarkan hasil penelitian yang telah dilaksanakan maka diperlukan penelitian lebih lanjut tentang antigenitas protein VirB4 $B$. abortus isolat lokal yang ditemukan sebagai kandidat kit diagnostik atau kandidat vaksin.

\section{UCAPAN TERIMA KASIH}

Penulis mengucapkan terimakasih kepada para pembimbing penelitian, tim peneliti VirB4 Brucella abortus, dan dukungan dari keluarga sehingga penelitian ini dapat terlaksana dengan baik.

\section{DAFTAR PUSTAKA}

Agasthya AS, Isloor S, Prabhudas K. 2007. Brucellosis in high risk group individual. Ind J Med Microbiol 25(1): 28-31.

Ali BA, Huang TH, Salem HH, Xie QD. 2006. Influence ot Thermal Cycler Day to Day Reproducibility of Random Amplified Polymorphic DNA Fingerprint. Biotechnology (5): 324-329.

Celli J, de Chastellier C, Franchini DM, PizarroCerda J, Moreno E. 2003. Brucella evades macrophage killing via VirB-dependent sustained interactions with the endoplasmic reticulum. J Exp Med 198: 545-556.

Lin J, Ficht TA. 1995. Protein synthesis in Brucella abortus induced during macrophage infection. Infectious Immunology 63: 1409-1414.
Megid J, Mathias LA, Robles CA. 2010. Clinical manifestations of brucellosis in domestic animal and human. The Open Vet Sc J 4: 119-126.

Nijskens C, Copin R, De Bolle X, Letesson JJ. 2008. Intracellular rescuing of a B. melitensis $16 \mathrm{M}$ VirB mutant by co-infection with a wild type strain. Microb Pathog 45: 134-141.

Noor SM. 2006. Epidemiologi dan Pengendalian Brucellosis pada Sapi Perah di Pulau Jawa. Bogor. Balai Besar Penelitian Veteriner Bogor.

Novagen ACG, Richard RB. 2007. Preparation of Protein Samples for SDS-Polyacrylamide Gel Electrophoresis in procedures and tips. Madison. WI 53706:10. Laboratory for Cancer Research. University of WisconsinMadison.

Pasquevich A, Samartino CG, Coria LM, Estein SM, Zwerdling A. 2010. Self-Adjuvanting Vaccine against Systemic and Immune Response, and Is a Promising Activates Dendritic Cells In Vivo, Induces a Th1 Pathogen-Associated Molecular Pattern That Membrane Protein 16 Is a New Bacterial and Oral Acquired Brucellosis. Journal Immunology 184: 5200-5212.

Pitt A, Mayorga LS, Stahl PD, Schwartz AL. 1992. Alterations in the protein composition of maturing phagosomes. J Clin Invest 90: 1978-1983.

Pizarro-Cerda J, Meresse S, Parton RG, van der Goot G, Sola-Landa A. 1998. Brucella abortus transits through the autophagic pathway and replicates in the endoplasmic reticulum of nonprofessional phagocytes. Infect Immun 66: 5711-5724.

Rand ND, Laing MD. 2011. Sodium dodecyl sulphate polyacrylamide gel electrophoresis (SDS-PAGE) of crude extracted insecticidal crystal proteins of Bacillus thuringiensis and Brevibacullus laterosporus. African Journal of Biotechnology 10(66): 15094-15099.

Rouot B, Martinez A, Marius C, Menanteau P, Guilloteau L, Boigegrain RA, R Zumbihl, O'Callaghan D. 2003. Production of The Type IV Secretion System Differs Among Brucella Species as Revealed With VirB5and VirB8-Specific Antisera. Infection and Immunology Journal 71: 1075-1082. 
Roy S, Vikash K. 2012. A Practical Approach on SDS PAGE for Separation of Protein. International Journal of Science and Researc 3: 955-960.

Sangari FJ, Aguero J, Garcia-Lobo JM. 2000. The genes for erythritol catabolism are organized as an inducible operon in Brucella abortus. Microbiology 146: 487-495.

Splitter GA. 2003. Molecular host-pathogen interaction in brucellosis: current understanding and future approaches to vaccine development for mice and humans. Clin Microbiol Rev 16: 65-78.

Sudibyo A. 1995. Studi Epidemiology Brucellosis dan Dampaknya terhadap Reproduksi Sapi
Perah di DKI Jakarta. Jurnal IlmuTernak dan Veteriner 1: 31-36.

Taminiau B, Daykin M, Swift S, Boschiroli ML, Tibor A. 2002. Identification of a quorumsensing signal molecule in the facultative intracellular pathogen Brucella melitensis. Infect Immun 70: 3004-3011.

Toelihere MR. 1985. Ilmu Kebidanan Pada Ternak Sapi dan Kerbau. UI. Press. Jakarta.plasmids. Methods Mollecular Biologi 47: 143-148.

Wilson K, Walker J. 2010. Principles and Tecniques of Biochemistry and Molekular Biology. $7^{\text {th }}$ Edition. Cambridge. Cambridge University Press. 